\title{
Necessity for LH in selection and continued growth of the bovine dominant follicle
}

\author{
Victor E Gomez-Leónn ${ }^{1,2,3}$, O J Ginther ${ }^{1,4}$, Rafael R Domingues ${ }^{1,4}$, José D Guimarães ${ }^{3}$ and \\ Milo C Wiltbank ${ }^{2}$ \\ ${ }^{1}$ Eutheria Foundation, Cross Plains, Wisconsin, USA, ${ }^{2}$ Department of Dairy Science, University of Wisconsin- \\ Madison (UW-Madison), Madison, Wisconsin, USA, ${ }^{3}$ Department of Veterinary Medicine, Universidade Federal de \\ Viçosa, Viçosa, Brazil and ${ }^{4}$ Department of Pathobiological Science, School of Veterinary Medicine, UW-Madison, \\ Madison, Wisconsin, USA
}

Correspondence should be addressed to M C Wiltbank; Email: wiltbank@wisc.edu

\begin{abstract}
Previous research demonstrated that acute treatment with GnRH antagonist, Acyline, allowed follicle growth until $\sim 8.5 \mathrm{~mm}$ and no dominant follicle was selected. This study evaluated whether deficient LH was the underlying mechanism for Acyline effects by replacing LH action, using human chorionic gonadotropin (hCG), during Acyline treatment. Holstein heifers $(n=24)$ during first follicular wave were evaluated by ultrasound and randomized into one of three treatments: Control (saline treatments), Acyline (5 $\mu \mathrm{g} /$ kg Acyline), or Acyline+hCG (Acyline plus 50 IU of hCG at start then 100 IU every 12 h). Pulses of LH were present in Control heifers (9 Pulses/10 h) but not during Acyline treatment. Data were normalized to the transition to diameter deviation (day 0; F1 7.5 mm). Diameter deviation of the largest (F1) and the second largest (F2) follicle was not observed in Acyline-treated heifers, whereas control heifers had decreased growth of F2 at F1 $\sim 7.5 \mathrm{~mm}$, indicating deviation. Selection of a single dominant follicle was restored by providing LH activity in Acyline+hCG heifers, as evidenced by F1 and F2 deviation, continued growth of F1, and elevated circulating estradiol. Separation of F1 and F2 occurred $12 \mathrm{~h}(\sim 7.0 \mathrm{~mm})$ earlier in Acyline+hCG heifers than Controls. Circulating FSH was greater in Acyline than Controls, but lower in Acyline+hCG than Controls after day 1.5. In conclusion, dominant follicle selection and growth after follicle deviation is due to $\mathrm{LH}$ action as shown by inhibition of this process during ablation of $\mathrm{GnRH}$-stimulated $\mathrm{LH}$ pulses with Acyline and restoration of it after replacement of LH action by hCG treatment.

Reproduction (2020) $\mathbf{1 5 9}$ 559-569
\end{abstract}

\section{Introduction}

In monovulatory species such as cattle, horses, and humans, ovarian follicle activity occurs in waves generally resulting in selection of a single dominant follicle (Ginther et al. 1996, 2001a, Mihm \& Evans 2008, Garcia-Guerra et al. 2018). A surge in circulating folliclestimulating hormone $(\mathrm{FSH})$ precedes the emergence of each wave (Adams et al. 1992). The follicles of each major follicular wave in the three monovulatory species undergo a common growth phase for 2 or 3 days after the peak of the FSH surge. At the end of the common growth phase in each species, diameter deviation begins which is the morphological manifestation of follicle selection (Ginther 2016). The beginning of diameter deviation between the future dominant follicle (F1) and the future largest subordinate follicle (F2) is the last examination in which diameter of F1 and F2 have not yet separated. During the first follicular wave, the beginning of diameter deviation occurs in Bos taurus heifers when F1 reaches $8.5 \mathrm{~mm}$ (Ginther 2016). However, there appears to be a transition that begins about $12 \mathrm{~h}$ before diameter deviation, or when the future dominant follicle reaches about $7.5 \mathrm{~mm}$ in diameter, and the follicle prepares to become dominant due to changes in follicular fluid factors and granulosa cell function (Beg \& Ginther 2006, Ginther 2016).

Diameter deviation occurs near the nadir in the wave-stimulating FSH surge (Ginther et al. 2000) and is coincident with a number of changes in gene expression in granulosa cells of the future dominant follicle including increased mRNA for CYP19A leading to increased follicular IGF1 production, increased mRNA for an IGF-1-binding protein protease (PAPPA) leading to increased free IGF-1 in the follicular fluid, and increased mRNA for luteinizing hormone receptors (LHr) (Ireland \& Roche 1983, Xu et al. 1995, Mihm et al. 2006, Luo et al. 2011). It has been postulated that acquisition of $\mathrm{LHr}$ in the granulosa cells allows LH pulses to drive growth of the dominant follicle after the beginning of diameter deviation, whereas the subordinate follicles undergo atresia in the presence of low circulating 
FSH (Ginther et al. 1996). Previous research in our laboratory (Haughian et al. 2013) found that short-term treatment with a GnRH antagonist, Acyline, during the first follicular wave suppressed $\mathrm{GnRH}$-stimulated $\mathrm{LH}$ secretion but not circulating FSH and led to cessation of growth of the largest follicle at about $8 \mathrm{~mm}$ with inhibition of follicle diameter deviation and a subsequent increase in circulating FSH concentration . Other more chronic models, such as hypophysectomy (Mcnatty et al. 1990), hypothalamo-pituitary disconnection (Clarke et al. 1983), immunization against GnRH (Crowe et al. $2001 a, b)$, or chronic treatment with GnRH receptor antagonist (Taylor et al. 2004, Webb et al. 2016) or potent GnRH agonist (Gong et al. 1996) indicated a role for LH but also a need for $\mathrm{FSH}$ in order to complete follicle development. However, acute experimental depression of $\mathrm{LH}$ by an acute $\mathrm{GnRH}$ antagonist treatment, leaving circulating FSH at normal concentrations, combined with the replacement of only $\mathrm{LH}$ action has not been used to determine the temporal relationship between the reduction in F1 growth and the transitional period and whether deficient $\mathrm{LH}$ accounted for the lack of the development of follicle dominance.

The present study focused on the role of $\mathrm{LH}$ in follicle selection. Thus, our primary biological hypothesis was that $\mathrm{LH}$ action is required for selection of a dominant follicle, including the transition to follicle selection, and for continued growth of the dominant follicle after the follicle deviation process. This hypothesis was postulated based on the observation that increased $\mathrm{LHr}$ in the granulosa cells of F1 occurs near diameter deviation and suppression of $\mathrm{LH}$ leads to lack of $\mathrm{LHr}$ expression and cessation of follicle growth (Xu et al. 1995, Beg et al. 2001, Ginther et al. 2001b, Mihm et al. 2006, Luo et al. 2011). This hypothesis was tested by acutely inhibiting $\mathrm{GnRH}$-induced $\mathrm{LH}$ secretion using a potent $\mathrm{GnRH}$ antagonist, Acyline, and by restoring the loss of $\mathrm{LH}$ function with a specific LHr agonist, hCG. The effect of $\mathrm{LH}$ on diameter of both F1 and F2 was considered. The reference point was the expected transition (F1 7.5 $\mathrm{mm}$ ) that precedes the beginning of diameter deviation (F1 $\sim 8.5 \mathrm{~mm}$ ). The specific experimental hypotheses were (1) treatment with a potent $\mathrm{GnRH}$ antagonist, Acyline, would inhibit LH pulses and result in lack of selection, growth, and functionality of a dominant follicle (after $\sim 7.5 \mathrm{~mm}$ ) and inhibition of follicle diameter deviation. This would lead to increased circulating FSH (Haughian et al. 2013). (2) Replacement of LH action in Acyline-treated heifers using a specific LHr agonist, hCG, would restore normal selection, growth, and function of a single dominant follicle with resulting growth and deviation from the subordinate follicles and suppressed circulating FSH. In this study, hCG was used rather than an $\mathrm{LH}$ preparation due to greater purity of protein, given that pituitary LH preparations have some contamination with FSH (Ellis 1961; Gomez-Leon et al. 2020) and because hCG is a pure LH receptor agonist
(Moyle et al. 1994). One advantage, as well as limitation, is that the hCG molecule has a longer half-life than LH (Nascimento et al. 2013). Therefore, our experimental design of twice-daily hCG treatments allowed LH activity to remain elevated throughout the experimental period to specifically test our biological hypothesis of the role of $\mathrm{LH}$ in follicle selection, but it did not allow us to mimic the circulating $\mathrm{LH}$ pulse patterns that occur during normal follicle selection.

\section{Materials and methods}

\section{Heifers, synchronization of ovulations, and ultrasound examinations}

The present experiment used Holstein heifers 24-monthold with a weight of $508 \pm 12 \mathrm{~kg}$. There were no apparent abnormalities in the reproductive tract as evaluated by ultrasound. The experiment was conducted during April and March in the northern temperate zone. The heifers were kept under natural light in open shelters and provided with ad libitum access to water, mineralized salt, and grass hay supplemented with ground corn in the winter. All experimental procedures and heifers were managed in accordance with the United States Department of Agriculture Guide for Care and Use of Agricultural Animals in Research under an animal protocol (\#A005727) that was approved by the Animal Care and Use Committee of the University of Wisconsin-Madison.

Prior to the experiment, heifers at random days of the interovulatory interval were pre-synchronized with a 5-day CIDR-synch protocol (Lima et al. 2011) with adaptations made in our laboratory: D-9, $200 \mu \mathrm{g}$ GnRH i.m. (gonadorelin acetate; Gonabreed $(\mathbb{B}$, Parnell Pharmaceuticals, Overland Park, KS, USA) and insertion of an intravaginal Controlled Internal Drug Release device (CIDR) with $1.38 \mathrm{~g}$ of P4 (Eazi-

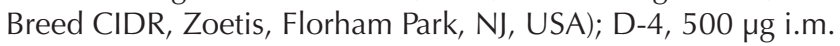

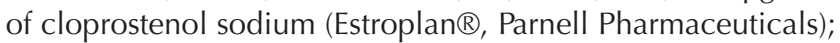
and D-3, $500 \mu \mathrm{g}$ i.m. of cloprostenol sodium (Estroplan $\AA$, Parnell Pharmaceuticals) and withdrawal of the CIDR. Starting on D-2, ultrasound scans were done every $12 \mathrm{~h}$ for detection of ovulation (D0). Unlike previous versions of the 5-day CIDRSynch protocol, no GnRH was given at the end of the protocol to induce ovulation. Ovulation occurred 3 days after removal of the CIDR (D-3) and only heifers that had synchronized ovulation on D0 were used.

Diameter of the four largest follicles was measured every $12 \mathrm{~h}$ starting at ovulation (D0). For that purpose, ultrasound examinations were done using a Mindray M5-Vet machine (Mindray North America, Mahwah, NJ, USA) with a multifrequency linear transducer set at 5.0-MHz. The dual-B-mode was used to obtain a video of each ovary on each side of the screen. The video recorded each individual ovary with a slow ultrasound scan from the outer- to the inner-most part of ovary or vice versa. Videos were evaluated frame by frame to aid identification of individual follicles from examination to examination. Measurements were done with the heifer still in the chute, allowing a second ultrasound video to be recorded, if necessary. Antral diameter was based on two perpendicular measurements (height and width) at the apparent maximal area 
of the well-focused antrum, as described previously (Pierson \& Ginther 1988).

\section{Treatments}

Each heifer was randomized into one of three groups $(n=8$ / group) when the largest growing follicle of the periovulatory wave (wave 1) reached or exceeded $5.5 \mathrm{~mm}$ in diameter. The treatment groups were Controls, Acyline, and Acyline+hCG. The Controls received a single saline treatment $(1 \mathrm{~mL})$. Acyline heifers, received a single i.m. dose of $5 \mu \mathrm{g} / \mathrm{kg}$ of Acyline (2.2 $\mathrm{mg} / \mathrm{mL}$ ), a GnRH antagonist from NIH/NICHD (Lot RDZ1007). Acyline+hCG heifers received a single i.m. treatment of $5 \mu \mathrm{g} / \mathrm{kg}$ of Acyline with an initial i.m. hCG dose of $50 \mathrm{IU}$ and subsequent doses of $100 \mathrm{IU}$ hCG i.m. every 12 h $(50 \mathrm{IU} / \mathrm{mL}$; Chorulon ${ }^{2}$, Merck Sharp \& Dohme Corp) until D6.5. The single treatment with $5 \mu \mathrm{g} / \mathrm{kg}$ of Acyline was based on complete inhibition of the $\mathrm{LH}$ and $\mathrm{FSH}$ response to $100 \mu \mathrm{g}$ of $\mathrm{GnRH}$ by a single treatment with either 3 or $10 \mu \mathrm{g} / \mathrm{kg}$ of Acyline (Haughian et al. 2013). The doses and frequency of the hCG treatment was intended to maintain a fairly constant elevation in LH activity and not to mimic the endogenous LH pulse secretion profile. The hCG dose was based on a previous study showing that the minimum non-ovulatory dose that stimulated dominant follicle growth was $200 \mathrm{IU}$ (Prata et al. 2018), whereas the frequency was based on a previous study that characterized the long half-life of hCG (Nascimento et al. 2013).

\section{Follicles}

The follicle that reached the largest diameter (F1) was plotted every $12 \mathrm{~h}$ from its emergence at $4 \mathrm{~mm}$. The second and third largest follicles (F2 and F3) were also plotted based on identification on the day that the F1 diameter was closest to $7.5 \mathrm{~mm}$ (day 0). Normalization to $7.5 \mathrm{~mm}$ F1 was done owing to an expected absence of diameter deviation at $8.5 \mathrm{~mm}$ in the Acyline-treated heifers (Haughian et al. 2013) and an F1 diameter of $7.5 \mathrm{~mm}$ at the expected beginning of the transition that precedes diameter deviation. Diameter deviation for waves that had an F1 $\geq 12 \mathrm{~mm}$ was classified as previously described (Ginther et al. 2016), based on the F2 diameter on the day that F1 was closest to $8.5 \mathrm{~mm}$ as follows: (1) conventional (F2 $\geq 7 \mathrm{~mm}$ ), (2) F2-undersized (F2 <7 mm), (3) F1, F2-switched (F2 larger than F1 on the day before or at deviation), and (4) co-dominant follicles (both F1 and F2 reached $10 \mathrm{~mm}$ ), in order to exclude data from switched deviations from all analyses. Only one heifer with switched deviation was observed (Control group) and was excluded from all the analyses since this class has been associated with specific changes in circulating FSH concentrations (Ginther 2018).

\section{Hormone assays}

Blood samples were collected prior to each ultrasound examination from the coccygeal vein of all heifers in the experiment ( $n=24)$. Additionally (within the same experiment), four heifers were evaluated from each group in order to collect blood samples every 15 min during a 10-h period starting 2 $\mathrm{h}$ after day 1.5 post ovulation. For this purpose, the heifers were placed in a restraint chute and catheters were placed as follows: The area over the jugular vein was shaved and cleaned with neutral soup and water, followed by rinsing with alcohol (70\%) and finally application of $10 \%$ povidone-iodine solution. Local anesthetic was administered subcutaneously to facilitate the insertion of the catheter. The catheter was fixed with a nylon suture and attached to an extension tube with a cap to facilitate the blood sample collections. The catheter was flushed with $10 \mathrm{~mL}$ of heparinized $(10 \mathrm{IU} / \mathrm{mL})$ saline solution after initial placement and after each blood sample collection. Thus, $10 \mathrm{~mL}$ of blood was discarded prior to each blood collection. These procedures were performed to obtain information on the effect of the treatments on the FSH and LH pulse patterns. An LH (FSH) pulse was designated when the following two criteria were met: (1) the S.D. of three consecutives samples was greater than three times the interassay $\mathrm{CV}$ for $\mathrm{LH}$ or two times greater than the inter-assay $\mathrm{CV}$ for FSH; and (2) the S.D. between a given sample and the basal $30 \%$ of values for an individual heifer was greater than three times the inter-assay CV for LH or two times greater than the inter-assay $\mathrm{CV}$ for $\mathrm{FSH}$.

All blood samples were collected into heparinized tubes immediately placed on ice until centrifugation (2000 $\mathbf{g}$ for $10 \mathrm{~min})$. The resulted plasma samples were collected and pipetted into $7 \mathrm{~mL}$ vials for storage at $-20^{\circ} \mathrm{C}$ until hormone assay. The FSH and LH concentrations were determined using a validated RIA technique (Bolt \& Rollins 1983, Bolt et al. 1990) with modifications reported previously (Adams et al. 1992, Ginther et al. 1999). The FSH intra- and inter-assay CV and the mean assay sensitivity were $8.5 \%, 4.4 \%$, and 0.035 $\mathrm{ng} / \mathrm{mL}$, respectively. The $\mathrm{LH}$ intra- and inter-assay $\mathrm{CV}$ and the mean assay sensitivity were $3.2 \%, 6 \%$, and $0.052 \mathrm{ng} /$ $\mathrm{mL}$, respectively. Estradiol (E2) concentrations on day -1.5 , day 0 ( $\mathrm{F} 1 \sim 7.5 \mathrm{~mm})$, day 1.5 , and day 3 were determined using a commercial ${ }^{125}$ I Ultra-Sensitive E2 RIA DSL-4800 kit (Beckman Coulter). Procedures for the E2 assay were similar to previous assays done in our laboratory (Kulick et al. 1999) but with the following modifications. The non-specific binding (NSB), maximum binding (B0), and a serial dilution for the standard curve (STD) were prepared in steer plasma. A total of $0.5 \mathrm{~mL}$ of each experimental plasma sample was analyzed in duplicates. All samples, including the NSB, B0, and STD, were double-extracted by adding $2.5 \mathrm{~mL}$ of diethyl ether to each tube, vortexing for $1.5 \mathrm{~m}$, followed by freezing the plasma in a methanol dry ice bath and pouring off the aqueous phase into a new tube. The ether was then evaporated overnight in a water bath. On the second day, resuspension was performed by addition of $0.5 \mathrm{~mL}$ of assay buffer and vortexing for $3 \mathrm{~min}$ followed by addition of the primary antibody and incubation for $1 \mathrm{~h}$. The ${ }^{125} \mathrm{I}$ tracer was added and then incubated for 2 $\mathrm{h}$ followed by addition of goat anti-rabbit gamma globulin serum in buffer with polyethylene glycol as a precipitating agent, vortexed for $20 \mathrm{~s}$, and incubation for $20 \mathrm{~min}$. Finally, the tubes were centrifuged, inverted to drain, and counted for $1 \mathrm{~min}$ in a gamma counter. The E2 intra-assay CV and the mean assay sensitivity were $12.2 \%$ and $0.21 \mathrm{pg} / \mathrm{mL}$, respectively. 


\section{Statistical analysis}

The F1 and F2 diameters as well as their growth rates $(\mathrm{mm} / 0.5$ d) and $\mathrm{FSH}$ and $\mathrm{LH}$ concentrations $(\mathrm{ng} / \mathrm{mL})$ were normalized to the day of Acyline treatment ( $F 1 \geq 5.5 \mathrm{~mm}$ ) or to the expected beginning of the transitional period (day 0; F1 $\sim 7.5 \mathrm{~mm}$ ), whereas E2 concentrations were only normalized to F1 7.5 $\mathrm{mm}$ and compared among groups. Values were transformed into natural logarithms or ranks when they were not normally distributed. Analyses were performed using SAS PROC MIXED (version 9.4; SAS Institute) with heifer treated as a random effect to account for the autocorrelation between sequential measurements. When a main effect or interaction was significant, Tukey's HSD test was used for comparisons. The frequency of deviation classes was compared among groups using Fisher's exact test. A probability of $P \leq 0.05$ indicated that a difference was significant, whereas a probability of $P>0.05$ to $P \leq 0.1$ indicated a trend or that significance was approached. Data are presented as the mean \pm S.E.M.

\section{Results}

The results on characterization of gonadotropin pulses from two representative heifers/group selected from the four heifers/group that had blood samples collected every $15 \mathrm{~min}$ for $10 \mathrm{~h}$ on day 1.5 post-ovulation are presented in Fig. 1. The detected LH pulses were more frequent $(P<0.0001)$ and of greater amplitude in the 4 Controls $(9.0 \pm 0.7$ pulses $/ 10 \mathrm{~h})$ when compared to the almost non-detectable pulses for LH observed in any of the eight individual heifers in the Acyline and Acyline $+\mathrm{hCG}$ groups $(0.1 \pm 0.5$ pulses $/ 10 \mathrm{~h})$. Detected FSH pulses had much lower frequency/amplitude in all groups and were difficult to detect when compared to the distinct LH pulses in the Controls.

The average follicle diameter profile of F1, F2, and F3 for each group, normalized to the expected beginning of the transitional period (day 0; F1 $\sim 7.5 \mathrm{~mm}$ ) is shown (Fig. 2) for each of the treatment groups. In the Controls (Fig. 2A), observed diameter deviation occurred between 0 to 0.5 days after $\mathrm{F} 1$ reached the day of the expected beginning of the transitional period (F1 $7.5 \mathrm{~mm}$ ). In the Acyline group (Fig. 2B), growth rate of F1 appeared to decrease when near a diameter of $7.5 \mathrm{~mm}$ (day 0), although the maximum diameter was reached on day $2(8.7 \pm 0.5 \mathrm{~mm})$. Diameter of F2 seemed unaffected. Therefore, follicle selection or diameter deviation was not apparent in the Acyline group. In the Acyline+hCG group (Fig. 2C), diameter of F1 was normal and growth rate after deviation was reestablished by addition of hCG to the Acyline treatment. Moreover, observed diameter deviation occurred on day -0.5 , as manifested by a lack of growth of F2 from -0.5 to 0 . Thus, observed diameter deviation occurred $12 \mathrm{~h}$ earlier in the Acyline+hCG group as compared to the Controls.

The result for the comparison among treatments of the circulating gonadotropin concentration and follicle dynamics normalized to the day of treatments ( $F 1 \geq 5.5$
A

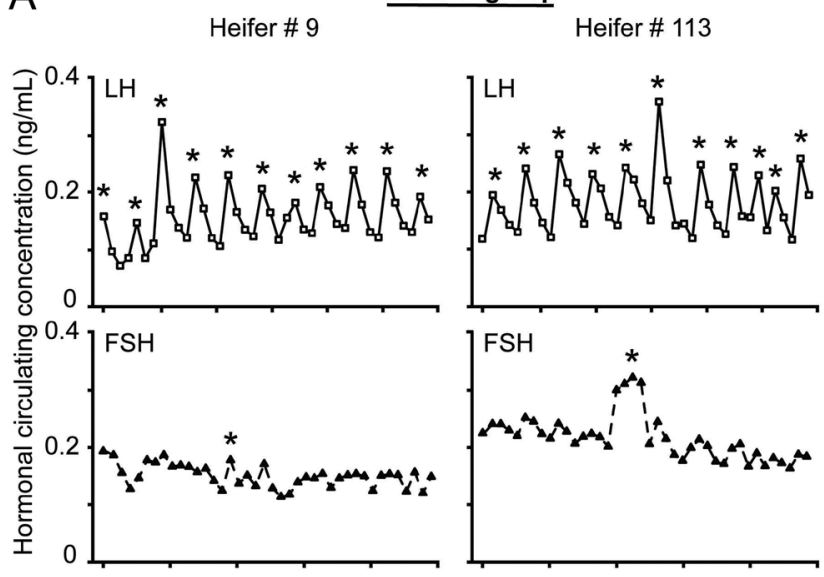

B Acyline group

Heifer \# 7

Heifer \# 12

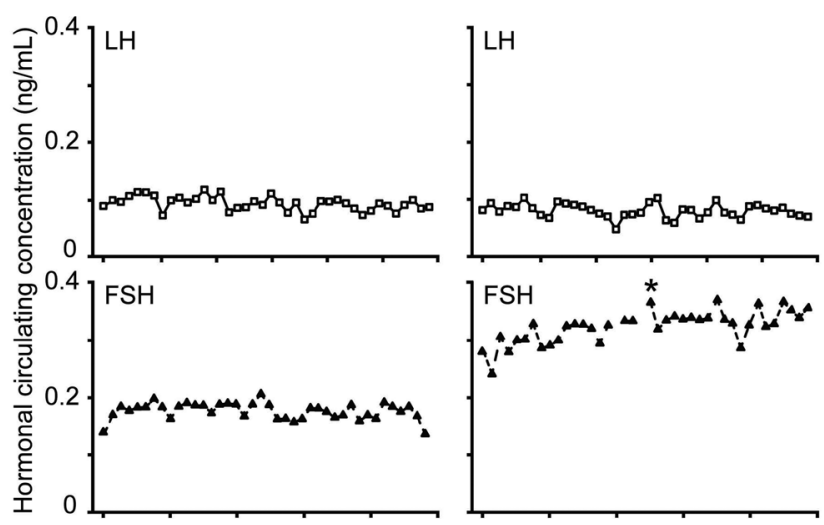

C

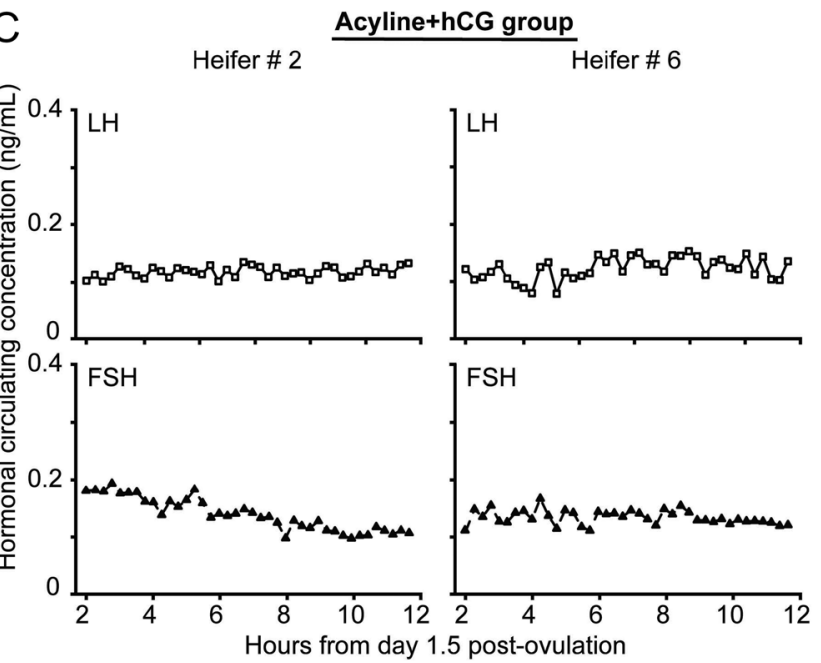

Figure $1 \mathrm{FSH}$ and LH pulse patterns from two representative heifers/ group selected from the four heifers/group collected every $15 \mathrm{~min}$ for a 10 -h period on day 1.5 post ovulation. Panel (A) shows two control heifers treated with saline solution; (B) two heifers treated with a single i.m. dose of Acyline, $5 \mu \mathrm{g} / \mathrm{kg}$ of body weight; and (C) two Acyline+hCG heifers treated with the Acyline dose plus additional treatment with an initial i.m. dose of $50 \mathrm{IU}$ and subsequent doses of $100 \mathrm{IU}$ of hCG/12 h. Treatments were performed on day 0.5 post ovulation. Asterisks indicate statistically detected LH and FSH pulses. 


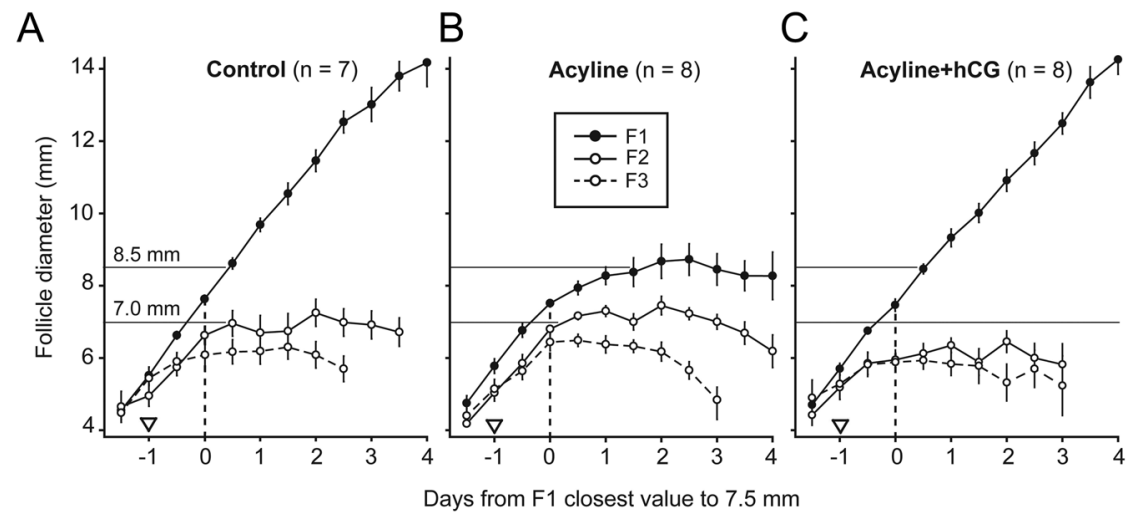

Figure 2 Mean \pm S.E.M. for the diameter of the largest or future dominant follicle (F1), second largest or future largest subordinate follicle (F2), and third largest follicle (F3) for each of the (A) Control $(n=7)$, (B) Acyline $(n=8)$ and (C) Acyline+hCG $(n=8)$ groups. Open, inverted triangles indicate (respectively) the mean day of saline treatment, single Acyline treatment $(5 \mu \mathrm{g} / \mathrm{kg})$, and Acyline $(5 \mu \mathrm{g} / \mathrm{kg})$ plus beginning of hCG treatment (initial dose of 50 $\mathrm{IU}$ and subsequent ones of $100 \mathrm{IU} / 12 \mathrm{~h}$ ). Data were normalized to $\mathrm{F} 1$ closest value to 7.5 $\mathrm{mm}$ (day 0 ).

$\mathrm{mm}$ ) was similar to the normalization to the transition to diameter deviation (F1 7.5 mm) and, thus, the first one is not shown. When the data were normalized to the day that F1 was closest to $7.5 \mathrm{~mm}$ (day 0; Fig. 3), the mean day for the start of treatments (largest growing follicle $\geq 5.5 \mathrm{~mm}$ ) was similar among the three groups $(-0.9 \pm 0.1 \mathrm{~d}$ before $\mathrm{F} 1$ reaching diameter closest to 7.5 $\mathrm{mm}$ ) and therefore was placed on day -1 . The main effects of group, main effect of day, and the group by day interaction were each significant for $\mathrm{LH}, \mathrm{FSH}, \mathrm{F} 1$, and F2. For the LH (Fig. 3A), the group effect was from greater concentration averaged over the days in the Control group $(0.17 \pm 0.01 \mathrm{ng} / \mathrm{mL})$ when compared to the Acyline and Acyline+hCG groups $(0.11 \pm 0.01 \mathrm{ng} /$ $\mathrm{mL}$ ). The interaction was primarily from decreasing concentration in the two Acyline groups during days -1 to 0 , lower concentration in these two groups from 0 to 2.5, and greater concentration in the Acyline group on day 4.

For circulating FSH concentrations (Fig. 3B) the group effect was from greater concentration averaged over the days in the Acyline group $(0.28 \pm 0.01 \mathrm{ng} /$ $\mathrm{mL})$, intermediate $(0.20 \pm 0.01 \mathrm{ng} / \mathrm{mL})$ in the Control, and lower $(0.16 \pm 0.01 \mathrm{ng} / \mathrm{mL})$ in the Acyline+hCG. The interaction was primarily from decreasing concentrations between days -1.5 to 0 on each of the three groups, as well as from greater concentrations in the Acyline group, intermediate concentration in the Control group and lower concentration in the Acyline+hCG group from days 1.5 to 4 .

For the F1 (Fig. 3C) diameter, the interaction was primarily from smaller size in the Acyline group than in the Control and Acyline+hCG groups during days 0.5 to 4 . The F1 maximum diameter was reached on day 4 for Controls and Acyline+hCG groups (14.2 $\pm 0.4 \mathrm{~mm})$, whereas for Acyline heifers the maximum diameter was reached on day $2(8.7 \pm 0.5 \mathrm{~mm})$. For the F2 (Fig. 3D) diameter, the interaction was primarily from smaller size in the Acyline+hCG group than in the Control and Acyline groups during days 0 and 0.5. For the F3 (not shown) diameter normalized to the expected beginning of transition, only the main effect of day was significant.
Growth rate of $\mathrm{F} 1$ from days -1.5 to $0(1.0 \pm 0.1$ $\mathrm{mm} / 0.5 \mathrm{~d}$ ) normalized to the expected beginning of transition (day 0; F1 $\sim 7.5 \mathrm{~mm}$ ) was similar among the three groups during each of the 0.5-day periods (Fig. 4). There was decreased F1 growth rate for each of the intervals from day 0 to 0.5 and 0.5 to 4 in the Acyline group when compared to the similarity between the other two groups. The F2 growth rate was similar among the three groups from each of the 0.5 -day periods from days -1.5 to $-0.5(0.8 \pm 0.1 \mathrm{~mm} / 0.5 \mathrm{~d})$. During days -0.5 to 0 , a lower F2 growth rate occurred in the Acyline+hCG group $(0.1 \pm 0.2 \mathrm{~mm} / 0.5 \mathrm{~d})$ when compared to the similarity in other two groups $(0.9 \pm 0.1 \mathrm{~mm} / 0.5 \mathrm{~d})$. The F2 growth rate during days 0 to 0.5 was similar among the three groups $(0.3 \pm 0.1 \mathrm{~mm} / 0.5 \mathrm{~d})$. The average growth rate $(-0.1 \pm 0.05 \mathrm{~mm} / 0.5 \mathrm{~d})$ from days 0.5 to 4 was similar and negative in each of the three groups.

Circulating E2 concentrations were analyzed (Table 1) among the three treatment groups (group comparisons) on each of the days $-1.5,0$ (F1 7.5 mm), 1.5, and 3; and within each group throughout the days (time comparison). On day -1.5 , E2 concentrations were low $(0.5 \pm 0.1 \mathrm{pg} /$ $\mathrm{mL}$ ) in all groups with no differences among treatments. Although E2 concentrations in the Acyline+hCG group increased $(366 \% ; P=0.05)$ from day -1.5 to 0 , there was no difference among the three groups on day $0(1.1 \pm 0.3$ $\mathrm{pg} / \mathrm{mL}$ ). E2 concentrations in the Acyline+hCG group tended $(P=0.07)$ to increase $(300 \%)$ from day -1.5 to 1.5 and there was a difference among the groups on day 1.5 with greater E2 concentrations in the Acyline+hCG group, intermediate concentrations in the Controls, and lower concentrations in the Acyline group. On day 3, the E2 concentrations tended to increase $(316 \%)$ in the Controls and increased (666\%) in the Acyline+hCG but not in the Acyline group. Thus, E2 concentrations on day 3 were greater in the Acyline+hCG, intermediate in the Controls, and lower in the Acyline group.

The class of diameter deviation was not determinable in the Acyline group because of the lack of diameter deviation or selection of a dominant follicle. The frequency of conventional diameter deviation was greater $(P<0.02)$ for the Controls $(6 / 8)$ than for the Acyline+hCG 


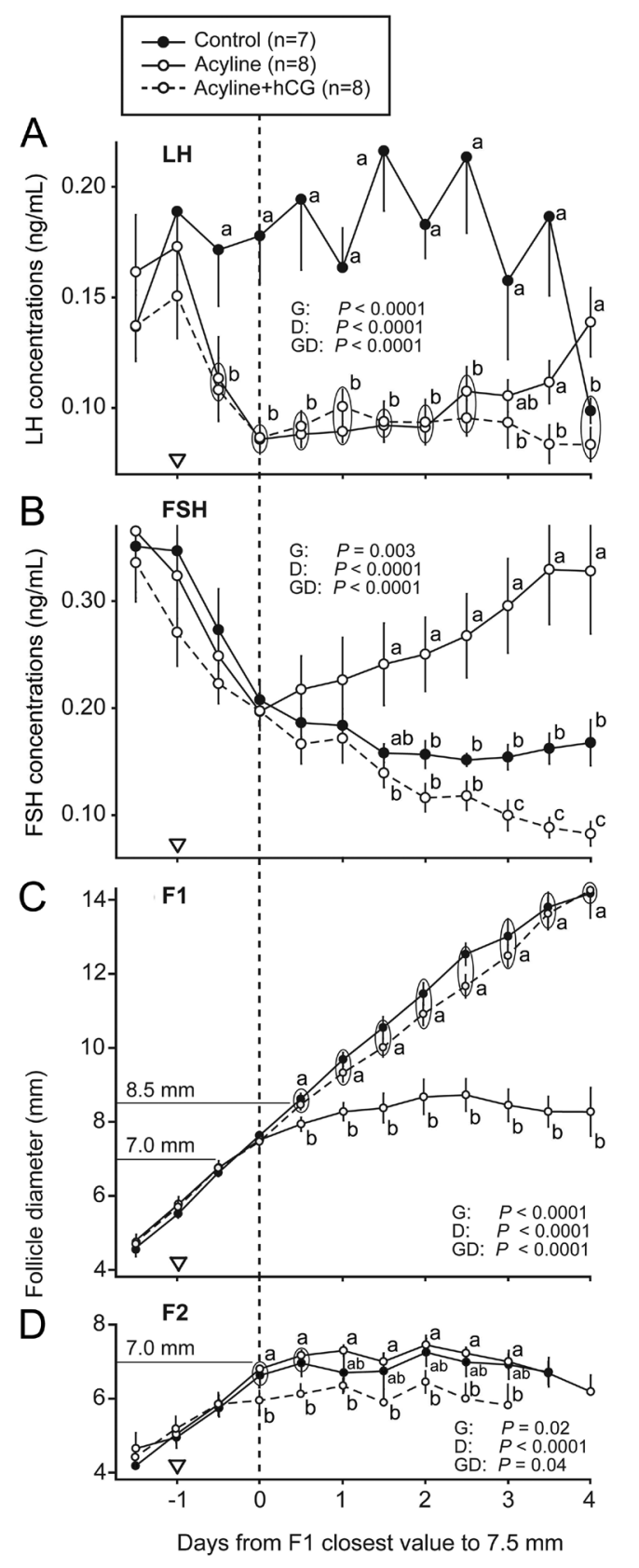

Figure 3 Mean \pm S.E.M. for the circulating concentrations of (A) LH and (B) FSH. In addition, accurate statistical comparisons are provided for the follicle growth data, represented graphically in Fig. 2, related to the diameter (C) of the largest or future dominant follicle (F1) and (D) the second largest or future largest subordinate follicle (F2). All groups, Control $(n=7)$, Acyline $(n=8)$ and Acyline+hCG $(n=8)$ were normalized to the transition to expected deviation (F1 $\sim 7.5 \mathrm{~mm}$ ). Open, inverted triangles indicate (respectively) the mean day of saline treatment, single Acyline treatment $(5 \mu \mathrm{g} / \mathrm{kg})$, and Acyline $(5 \mu \mathrm{g} / \mathrm{kg}$ ) plus beginning of hCG treatment (initial dose of $50 \mathrm{IU}$ and subsequent ones of $100 \mathrm{IU} / 12 \mathrm{~h}$ ). Probabilities for main effect of group (G), main effect of day (D) and interaction of group by day (GD) are indicated for each hormone and follicle category.

Lowercase letters indicate a difference among the groups when GD: $P \leq 0.05$.

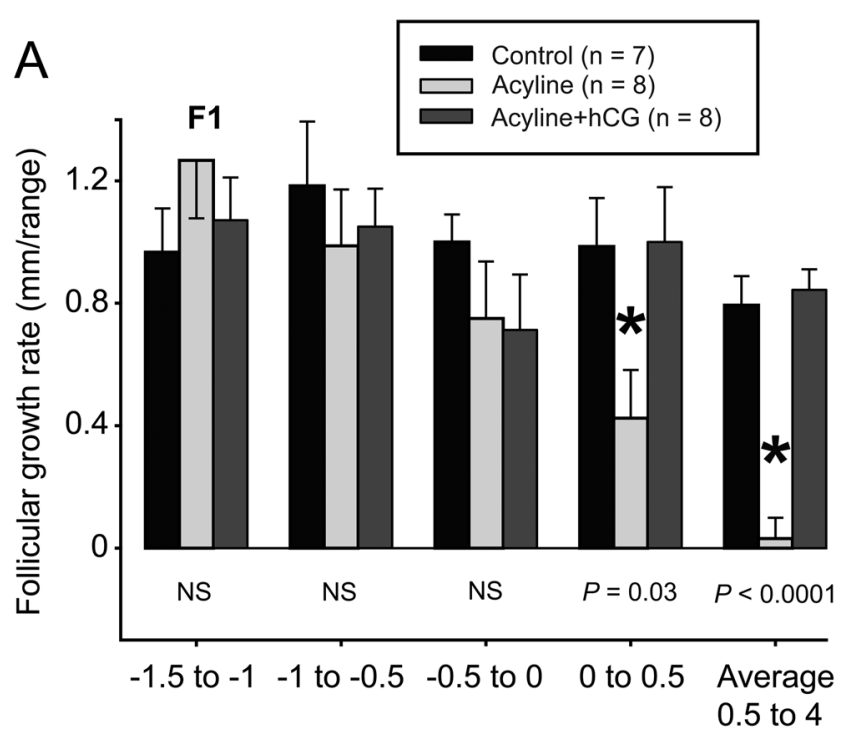

Range of days from F1 closest to $7.5 \mathrm{~mm}$ (day 0)

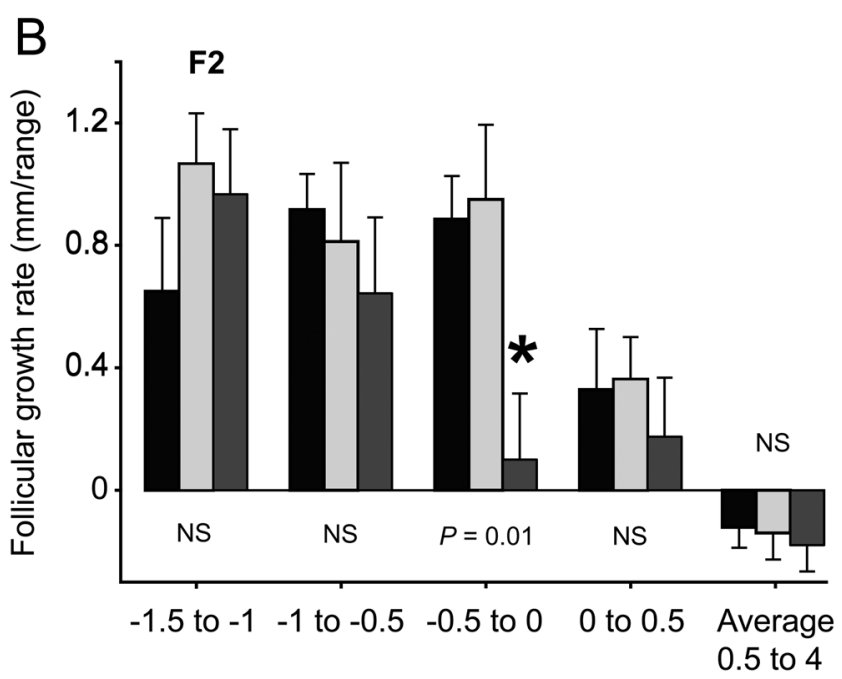

Range of days from F1 closest to $7.5 \mathrm{~mm}$ (day 0 )

Figure 4 Mean \pm S.E.M. for the growth rate $(\mathrm{mm} / 0.5 \mathrm{~d})$ of $(\mathrm{A})$ the largest or future dominant follicle (F1) and (B) the second largest or future largest subordinate follicle (F2) for each of the Control ( $n=7)$, Acyline $(n=8)$ and Acyline + hCG $(n=8)$ groups normalized to the transition to expected diameter deviation (day $0=\mathrm{F} 1 \sim 7.5 \mathrm{~mm}$ ). Treatments were performed at day -1 . Control heifers were treated with saline solution; Acyline heifers were treated with a single i.m. dose of 5 $\mu \mathrm{g} / \mathrm{kg}$ of body weight, whereas Acyline+hCG received the Acyline dose plus additional treatment with an initial i.m. dose of $50 \mathrm{IU}$ and subsequent doses of $100 \mathrm{IU}$ of hCG/12 h. An asterisk indicates the group that differ within a day when $P \leq 0.05$, whereas NS indicates that non-significant differences were detected among the group.

group (1/8), whereas the frequency of undersized class was greater $(P<0.005)$ in the Acyline+hCG group $(7 / 8)$ than in the Controls (1/8). Only one switched deviation was observed (Controls) and was excluded from all the analyses. 
Table 1 Circulating estradiol concentrations for each of the groups on days $-1.5,0$ (F1 7.5 mm), 1.5, and 3.

\begin{tabular}{|c|c|c|c|c|c|c|c|}
\hline \multirow[b]{2}{*}{ Groups } & \multicolumn{4}{|c|}{ Estradiol concentrations $(\mathrm{pg} / \mathrm{mL})$ on days } & \multicolumn{3}{|c|}{$P$-values for time ${ }^{a}$ comparisons, day -1.5} \\
\hline & -1.5 & 0 & 1.5 & 3 & to 0 & to 1.5 & to 3 \\
\hline Controls & $0.6 \pm 0.2$ & $1 \pm 0.3$ & $0.7 \pm 0.2^{\mathrm{cd}}$ & $1.9 \pm 0.8^{\mathrm{cd}}$ & 0.1 & 0.4 & 0.07 \\
\hline Acyline & $0.5 \pm 0.1$ & $0.7 \pm 0.4$ & $0.7 \pm 0.5^{\mathrm{d}}$ & $0.5 \pm 0.2^{\mathrm{d}}$ & 0.3 & 0.4 & 0.4 \\
\hline Acyline+hCG & $0.3 \pm 0.1$ & $1.4 \pm 0.6$ & $1.2 \pm 0.5^{\mathrm{c}}$ & $2.3 \pm 0.5^{c}$ & 0.05 & 0.07 & 0.001 \\
\hline$P$-values for group comparisons ${ }^{b}$ & 0.3 & 0.3 & 0.05 & 0.08 & & & \\
\hline
\end{tabular}

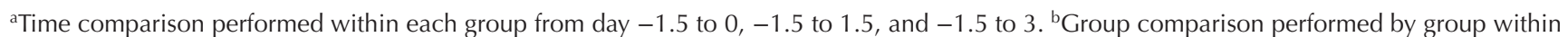
a day.

\section{Discussion}

Numerous studies have attempted to understand the molecular, cellular, paracrine, hormonal, and follicular dynamics that produce selection of a single dominant follicle from the cohort of follicles that are growing during a follicular wave (Fortune et al. 1991, Ginther et al. 1996, Crowe 1999, Ireland et al. 2000, Mihm et al. 2002, Webb et al. 2002 2016, Scaramuzzi et al. 2011, Ginther 2016, Garcia-Guerra et al. 2018) and yet all the mechanisms involved in this process have not been defined. This study focused on the role of circulating LH during the follicle selection mechanism. The use of precise characterization of follicular wave dynamics during ablation of LH pulses using acute treatment with a potent $\mathrm{GnRH}$ antagonist, Acyline, and subsequent replacement of $\mathrm{LH}$ action using a specific LHr agonist, hCG, allowed substantial insight into the hormonal control of follicle selection. The bovine model is particularly informative because of the extensive previous characterization of follicle dynamics and the complexities during follicle selection under different physiological conditions (Adams \& Pierson 1995, Ginther et al. 1996, 2016, Garcia-Guerra et al. 2018, Gomez-Leon et al. 2019).

Our first experimental hypothesis was supported, that Acyline treatment would decrease/eliminate LH pulses and inhibit follicle growth after expected diameter deviation ( 8.5 $\mathrm{mm}$ in Bos taurus cattle), also known as the morphological manifestation of follicle selection (Ginther 2016). There were essentially no detectable $\mathrm{LH}$ pulse frequency during the 10 -h frequent sampling period in heifers treated with Acyline compared to about 9 pulses $/ 10 \mathrm{~h}$ in the Control group, similar to the profile of $\mathrm{LH}$ pulses during the early luteal phase (Schallenberger et al. 1985, Ginther et al. 1998). Despite the diminished $\mathrm{LH}$ pulses, growth rate $(\sim 1 \mathrm{~mm} / 0.5 \mathrm{~d})$ of the $\mathrm{F} 1$ was identical until the time when the $\mathrm{F} 1$ reached a diameter $\sim 7.5 \mathrm{~mm}$. In addition, studies that inhibited circulating $\mathrm{FSH}$ led to reduced follicle growth during the common growth phase (prior to $8.5 \mathrm{~mm}$ ) (Turzillo \& Fortune 1990, Haughian et al. 2013). Thus, follicle growth until $0.5 \mathrm{~d}$ before expected diameter deviation is dependent upon circulating FSH but not $\mathrm{LH}$ concentrations.

The role of circulating $\mathrm{LH}$ concentrations on F1 growth after the expected time of diameter deviation have been elucidated in previous studies (Martinez et al. 1999, Duffy et al. 2000, Ginther et al. 2001b, Prata et al. 2018). Nevertheless, LH activity has not clearly been shown as the key limiting factor that prevents follicle selection during acute elimination of LH pulses. In that sense, our second experimental hypothesis was supported and represented the most important reason for this research, to determine whether the lack of follicle growth after $\mathrm{GnRH}$ antagonist treatment was reestablished by restoring only $\mathrm{LH}$ action. The $\mathrm{LH}$ action was restored by using hCG treatments although the treatments were not intended to mimic the endogenous LH pulse pattern. Instead, we used hCG to assure specificity for the LH receptor (Ellis 1961, Moyle et al. 1994). In addition, we used a low, non-ovulatory dose of hCG to assure that LH activity was continually present during the experimental period to validly test whether $\mathrm{LH}$ activity alone could restore the follicle selection process, in absence of endogenous LH pulses. The dose of hCG was chosen based on previous studies showing that this dose restored follicle growth in suckled beef cattle and that higher doses of hCG produced premature ovulations (Prata et al. 2018). There was a complete restoration of the expected $\mathrm{F} 1$ follicle growth profile (based on diameter) after replacement of LH activity during Acyline treatment, as can be observed in the follicular wave profile within each treatment group (Fig. 2), as well as from the accurate direct comparisons of the F1 diameter and growth rate (Figs 3 and 4). Thus, this study clearly demonstrates that the explanation for lack of selection, and F1 growth after $7.5 \mathrm{~mm}$ in heifers with acute treatment with $\mathrm{GnRH}$ antagonist is caused by insufficient LH activity. In addition, there was no change in growth rate for the $\mathrm{F} 1$ in response to treatment with hCG perhaps because follicle growth was maximally stimulated in the Control group due to the elevated $\mathrm{LH}$ activity that is characteristic of the first follicular wave.

Our primary biological hypothesis was that there is a physiological role for circulating $\mathrm{LH}$ concentrations in the growing follicles prior to deviation. In this regard, the F1 growth rate began to decline at about $7.5 \mathrm{~mm}$ in the Acyline-treated heifers compared to the other groups. This would represent about $0.5 \mathrm{~d}$ before expected diameter deviation (F1 8.5 mm) and suggests a potential role of $\mathrm{LH}$ during the transition that precedes expected diameter deviation (Ginther 2016). In agreement, acquisition of $\mathrm{LHr}$ in granulosa cells during this time has been associated with follicle selection (Luo et al. 
2011) or dominance (Xu et al. 1995, Bao et al. 1997). In addition, an observed minor LH surge (based on daily samples) has been reported to encompass deviation during the first but not the second follicular wave (Kulick et al. 2001). Our previous research indicated that there was a lack of induction of LHr, CYP19A1, and PAPPA in granulosa cells indicating that acquisition of the dominant follicle phenotype selection of a dominant follicle depends on LH (Luo et al. 2011).

The granulosa cells of the F1 but not the F2 increase LHr mRNA during F1 growth from 7.5 to $7.9 \mathrm{~mm}$ (Beg et al. 2001), a similar diameter to when we observed a decrease in growth rate of the F1 in the Acyline group in the current study. In addition, stimulation by LH of the cAMP/protein kinase A pathway in the granulosa cells of the selected follicle probably drives aromatase gene expression (CYP19A1) (Ginther et al. 1996, Fortune et al. 2001, Luo et al. 2011) and increased production of estradiol by the dominant follicle after $8.5 \mathrm{~mm}$ (Ginther et al. 1997, Beg et al. 2001). The elevation in circulating estradiol in the Control and Acyline+hCG heifers demonstrated the requirement for $\mathrm{LH}$ in the increase in follicular estradiol production. It is interesting that this increase in circulating E2 was significant by day 0 (F1 7.5 mm). This may indicate that the Acyline+hCG heifers had earlier acquisition of $\mathrm{LHr}$ in granulosa cells (at $7.5 \mathrm{~mm}$ rather than $8.5 \mathrm{~mm}$ ), although this idea remains to be directly tested. In addition, the role of $\mathrm{LH}$ in E2 production after deviation is clearly supported and it is likely that the increase in circulating E2 causes the suppression of circulating FSH that is observed in both Control and Acyline+hCG groups compared to the heifers treated with Acyline alone. Thus, the final suppression of FSH appears to require the presence of a functional dominant follicle, likely due to increased follicular E2 concentrations driven by $\mathrm{LH}$ action after deviation. Furthermore, heifers treated with Acyline+hCG had a greater suppression of FSH after deviation than observed in the Control heifers suggesting that hCG treatment led to greater FSH inhibitory activity secreted from the dominant follicle than observed during the intrinsic amounts of $\mathrm{LH}$ secretion during the first follicular wave. This observation agrees with the increased E2 concentrations observed in the Acyline+hCG group on days $0,1.5$, and 3 (day $0=\mathrm{F} 1 \sim 7.5 \mathrm{~mm}$ ) when compared to day -1.5. In addition, the continuous LH activity that is produced by the longer half-life of hCG, may cause greater E2 production and greater inhibition of $\mathrm{FSH}$ in the Acyline+hCG than in the Controls. Support for this idea is also provided by a recent study (Gong et al. 2019) that observed a decrease in circulating FSH concentrations when the frequency of a given ovine $\mathrm{LH}$ dose $(25 \mu \mathrm{g})$ was increased from every $4 \mathrm{~h}$ to every hour.

The increase in circulating FSH after Acyline treatment in this study differs from some observations in previous research. In our previous study (Haughian et al. 2013), the increase in circulating FSH began at about $6 \mathrm{~h}$ after
Acyline treatment and FSH continued to be elevated for a number of hours, compared to Controls. In the present experiment, we observed a delay in the Acylineinduced increase in $\mathrm{FSH}$ with significant increases only observed $2 \mathrm{~d}$ after Acyline treatment (Fig. 3). However, in the previous experiment, Acyline treatment began prior to wave emergence ( $22 \mathrm{~h}$ before ovulation) compared to the later time in the follicular wave $(>5.5$ $\mathrm{mm}$ ) utilized in this experiment. A recent study reported a complete suppression of circulating $\mathrm{LH}$ but a failure to suppress circulating FSH during a 21-day treatment period using about 5 -fold greater doses of Acyline than those used in the present study (Jimenez-Krassel et al. 2018). Inhibition of GnRH-stimulated FSH secretion, as observed in this study, failed to suppress circulating FSH concentration, at least in the acute time period used in this study, consistent with the idea that circulating FSH is primarily driven by a $\mathrm{GnRH}$-independent regulation termed constitutive FSH secretion, which is controlled by inhibitory factors produced by the growing follicles and subsequently by the dominant follicle (Mcneilly 1988, Padmanabhan et al. 2003). Thus, Acyline treatment did not suppress circulating FSH in heifers, in contrast to results observed in mares and women (Herbst et al. 2002, Checura et al. 2009).

Acyline treatment inhibits GnRH-stimulated $\mathrm{FSH}$ pulses. In this regard, treatment of heifers with Acyline and hCG resulted in earlier F2 growth rate decrease. In addition, diameter separation of the F2 occurred at a smaller size in the Acyline+hGG heifers than in Control heifers, in spite of the similarity in the growth characteristics for the F1 between these groups. Consistent with this idea, heifers treated with Acyline+hCG primarily had undersized follicle deviation, compared to Control heifers (7/8 vs 1/8) which primarily exhibited conventional deviation. Prior to the experiment, we postulated that treatment with hCG would cause increased frequency of undersized classes based on our previous studies (Gomez-León et al. 2020) using hCG or pLH treatment during the second follicular wave. In that study, treatment with LH agonists decreased circulating $\mathrm{FSH}$ and growth rate of F2. In this study, the decrease in F2 growth rate in the Acyline + hCG treatment was associated with an increase in circulating E2 but the decrease in circulating $\mathrm{FSH}$, compared to Controls, did not occur until a time that was later than observed diameter deviation. The underlying basis for the earlier decrease in growth rate of the F2 during Acyline+hCG remains unclear but may relate to changes in FSH pulses. This study was not designed to definitively evaluate $\mathrm{FSH}$ pulse patterns, due to the low numbers of heifers that were evaluated. However, the FSH pulses were clearly less obvious in Control heifers compared to the $\mathrm{LH}$ pulses and are likely to have little impact on the average FSH concentrations that are monitored by 12-h blood sampling. Future studies should be designed to clearly test the regulation and 
physiological action of FSH pulses on follicle growth and diameter separation.

In conclusion, this study clearly demonstrates the physiologic role of LH activity in follicle selection and diameter deviation mechanisms as was evidenced by (1) inhibition of LH pulses/activity by the Acyline treatment, leading to (2) inhibition of follicle selection and diameter deviation; and (3) reestablishment of selection, growth, and functionality of a single dominant follicle by hCG treatment in the presence of Acyline treatment. The increased frequency of undersized deviations, as well as the increase in circulating E2 concentrations, and the further declines in circulating $\mathrm{FSH}$ observed in the Acyline+hCG group compared to Controls, suggest that there may be molecular differences in the selected dominant follicle of this two groups notwithstanding the similarities in their diameter. This would likely explain the earlier inhibition of F2 growth and greater declines in circulating $\mathrm{FSH}$ during hCG treatment. Future studies are needed to determine the precise molecular mechanisms that cause induction of $\mathrm{LH}$ responsiveness and the variations in diameter deviation, that is, $\mathrm{LHr}$ in the granulosa cells of the dominant follicle near deviation during different hormonal environments.

\section{Declaration of interest}

The authors declare that there is no conflict of interest that could be perceived as prejudicing the impartiality of the research reported.

\section{Funding}

Funding was provided by the Eutheria Foundation as Project B3-VG-18, WI Experiment Station as Hatch Project WIS01240 to M C W, and USDA-NIFA project 2018-67015-27612 to $\mathrm{MCW}$.

\section{Author contribution statement}

V G helped conceive of the research, designed and performed the study, analyzed the results, and wrote the manuscript; $\mathrm{O}$ J G helped conceive of the research, supervised the research and writing of the manuscript, and contributed, along with J $\mathrm{D}$, to the intellectual content in the manuscript; R D helped performed the study and assisted in the assays; M C W conceived of the ideas for the research, contributed during the research, directly supervised and provided intellectual input during the study and the analysis of the results, and helped write and revise the manuscript.

\section{Acknowledgments}

The authors thank Guilherme Madureira for validation and assistance with the estradiol assay as well as the National Institute of Child Health and Human Development of NIH for donation of the $\mathrm{GnRH}$ receptor antagonist, Acyline.

\section{References}

Adams GP, Matteri RL, Kastelic JP, Ko JC \& Ginther OJ 1992 Association between surges of follicle-stimulating hormone and the emergence of the follicular wave in heifers. Journal of Reproduction and Fertility 94 177-188. (https://doi.org/10.1530/jrf.0.0940177)

Adams GP \& Pierson RA 1995 Bovine model for study of ovarian follicular dynamics in humans. Theriogenology 43 113-120. (https://doi. org/10.1016/0093-691X(94)00015-M)

Bao B, Garverick HA, Smith GW, Smith MF, Salfen BE \& Youngquist RS 1997 Changes in messenger ribonucleic acid encoding luteinizing hormone receptor, cytochrome P450 side chain cleavage, and aromatase are associated with recruitment and selection of bovine ovarian follicles. Biology of Reproduction 56 1158-1168. (https://doi.org/10.1095/ biolreprod56.5.1158)

Beg MA, Bergfelt DR, Kot K, Wiltbank MC \& Ginther OJ 2001 Follicularfluid factors and granulosa-cell gene expression associated with follicle deviation in cattle. Biology of Reproduction 64 432-441. (https://doi. org/10.1095/biolreprod64.2.432)

Beg MA \& Ginther OJ 2006 Follicle selection in cattle and horses: role of intrafollicular factors. Reproduction 132 365-377. (https://doi. org/10.1530/rep.1.01233)

Bolt DJ \& Rollins R 1983 Development and application of a radioimmunoassay for bovine follicle stimulating hormone. Journal of Animal Science 56 146-154. (https://doi.org/10.2527/jas1983.561146x)

Bolt DJ, Scott V \& Kiracofe GH 1990 Plasma LH and FSH after estradiol, norgestomet and $\mathrm{GnRH}$ treatment of ovariectomized beef heifers. Animal Reproduction Science 23 263-271. (https://doi.org/10.1016/03784320(90)90040-M)

Checura CM, Beg MA, Gastal EL, Gastal MO, Wiltbank MC, Parrish JJ \& Ginther OJ 2009 Effect of suppression of FSH with a GnRH antagonist (Acyline) before and during follicle deviation in the mare. Reproduction in Domestic Animals 44 504-511. (https://doi.org/10.1111/j.14390531.2008.01222.x)

Clarke IJ, Cummins JT \& Dekretser DM 1983 Pituitary-gland function after disconnection from direct hypothalamic influences in the sheep. Neuroendocrinology 36 376-384. (https://doi.org/10.1159/000123484)

Crowe MA 1999 Gonadotrophic control of terminal follicular growth in cattle. Reproduction in Domestic Animals 34 157-166. (https://doi. org/10.1111/j.1439-0531.1999.tb01234.x)

Crowe MA, Enright WJ, Boland MP \& Roche JF 2001a Follicular growth and serum follicle-stimulating hormone $(\mathrm{FSH})$ responses to recombinant bovine FSH in GnRH-immunized anoestrous heifers. Animal Science 73 115-122. (https://doi.org/10.1017/S1357729800058112)

Crowe MA, Kelly P, Driancourt MA, Boland MP \& Roche JF $2001 b$ Effects of follicle-stimulating hormone with and without luteinizing hormone on serum hormone concentrations, follicle growth, and intrafollicular estradiol and aromatase activity in gonadotropin-releasing hormoneimmunized heifers. Biology of Reproduction 64 368-374. (https://doi. org/10.1095/biolreprod64.1.368)

Duffy P, Crowe MA, Boland MP \& Roche JF 2000 Effect of exogenous LH pulses on the fate of the first dominant follicle in postpartum beef cows nursing calves. Journal of Reproduction and Fertility 118 9-17. (https:// doi.org/10.1530/jrf.0.1180009)

Ellis S 1961 Bioassay of luteinizing hormone. Endocrinology 68 334-340. (https://doi.org/10.1210/endo-68-2-334)

Fortune JE, Sirois J, Turzillo AM \& Lavoir M 1991 Follicle selection in domestic ruminants. Journal of Reproduction and Fertility: Supplement 43 187-198. (https://doi.org/10.1530/biosciprocs.2.015)

Fortune JE, Rivera GM, Evans ACO \& Turzillo AM 2001 Differentiation of dominant versus subordinate follicles in cattle. Biology of Reproduction 65 648-654. (https://doi.org/10.1095/biolreprod65.3.648)

Garcia-Guerra A, Wiltbank MC, Battista SE, Kirkpatrick BW \& Sartori $\mathbf{R}$ 2018 Mechanisms regulating follicle selection in ruminants: lessons learned from multiple ovulation models. Animal Reproduction 15 660-679. (https://doi.org/10.21451/1984-3143-AR2018-0027)

Ginther OJ, Wiltbank MC, Fricke PM, Gibbons JR \& Kot K 1996 Selection of the dominant follicle in cattle. Biology of Reproduction $\mathbf{5 5}$ 1187-1194. (https://doi.org/10.1095/biolreprod55.6.1187)

Ginther OJ, Kot K, Kulick LJ \& Wiltbank MC 1997 Sampling follicular fluid without altering follicular status in cattle: oestradiol concentrations early in a follicular wave. Journal of Reproduction and Fertility 109 181-186. (https://doi.org/10.1530/jrf.0.1090181) 
Ginther OJ, Bergfelt DR, Kulick LJ \& Kot K 1998 Pulsatility of systemic FSH and LH concentrations during follicular-wave development in cattle. Theriogenology 50 507-519. (https://doi.org/10.1016/s0093$691 \times(98) 00157-5)$

Ginther OJ, Bergfelt DR, Kulick LJ \& Kot K 1999 Selection of the dominant follicle in cattle: establishment of follicle deviation in less than 8 hours through depression of FSH concentrations. Theriogenology 52 1079-1093. (https://doi.org/10.1016/S0093-691X(99)00196-X)

Ginther OJ, Bergfelt DR, Kulick LJ \& Kot K 2000 Selection of the dominant follicle in cattle: role of two-way functional coupling between folliclestimulating hormone and the follicles. Biology of Reproduction 62 920-927. (https://doi.org/10.1095/biolreprod62.4.920)

Ginther OJ, Beg MA, Bergfelt DR, Donadeu FX \& Kot K 2001a Follicle selection in monovular species. Biology of Reproduction 65 638-647. (https://doi.org/10.1095/biolreprod65.3.638)

Ginther OJ, Bergfelt DR, Beg MA \& Kot K $2001 b$ Follicle selection in cattle: role of luteinizing hormone. Biology of Reproduction $\mathbf{6 4}$ 197-205. (https://doi.org/10.1095/biolreprod64.1.197)

Ginther OJ 2016 The theory of follicle selection in cattle. Domestic Animal Endocrinology $57 \quad 85-99 . \quad$ (https://doi.org/10.1016/j. domaniend.2016.06.002)

Ginther OJ, Baldrighi JM, Siddiqui MA \& Araujo ER 2016 Complexities of follicle deviation during selection of a dominant follicle in Bos taurus heifers. Theriogenology $\mathbf{8 6}$ 2012-2019. (https://doi.org/10.1016/j. theriogenology.2016.06.025)

Ginther OJ 2018 Spontaneous switching of future dominance to a smaller follicle: commonality among monovular species. Biology of Reproduction 99 1129-1136. (https://doi.org/10.1093/biolre/ioy151)

Gomez-Leon VE, Ginther OJ, Araujo ER, Guimaraes JD \& Wiltbank MC 2019 Hormonal mechanisms regulating follicular wave dynamics I: comparison of follicle growth profiles under different physiological conditions in heifers. Theriogenology 123 194-201. (https://doi. org/10.1016/j.theriogenology.2018.09.006)

Gomez-León VE, Ginther OJ, Guimarães JD \& Wiltbank MC 2020 Hormonal mechanisms regulating follicular wave dynamics II: progesterone decreases diameter at follicle selection regardless of whether circulating FSH or LH are decreased or elevated. Theriogenology 143 148-156. (https://doi.org/10.1016/j.theriogenology.2019.11.003)

Gong JG, Campbell BK, Bramley TA, Gutierrez CG, Peters AR \& Webb R 1996 Suppression in the secretion of follicle-stimulating hormone and luteinizing hormone, and ovarian follicle development in heifers continuously infused with a gonadotropin-releasing hormone agonist. Biology of Reproduction 55 68-74. (https://doi.org/10.1095/ biolreprod55.1.68)

Gong JG, Campbell BK \& Webb R 2019 Defining the gonadotrophin requirement for the selection of a single dominant follicle in cattle. Reproduction, Fertility, and Development 32 322-334. (https://doi. org/10.1071/RD19060)

Haughian JM, Ginther OJ, Diaz FJ \& Wiltbank MC 2013 Gonadotropinreleasing hormone, estradiol, and inhibin regulation of folliclestimulating hormone and luteinizing hormone surges: implications for follicle emergence and selection in heifers. Biology of Reproduction $\mathbf{8 8}$ 165. (https://doi.org/10.1095/biolreprod.112.107342)

Herbst KL, Anawalt BD, Amory JK \& Bremner WJ 2002 Acyline: the first study in humans of a potent, new gonadotropin-releasing hormone antagonist. Journal of Clinical Endocrinology and Metabolism 87 3215-3220. (https://doi.org/10.1210/jcem.87.7.8675)

Ireland JJ \& Roche JF 1983 Development of nonovulatory antral follicles in heifers: changes in steroids in follicular fluid and receptors for gonadotropins. Endocrinology 112 150-156. (https://doi.org/10.1210/ endo-112-1-150)

Ireland J, Mihm M, Austin E, Diskin MG \& Roche JF 2000 Historical perspective of turnover of dominant follicles during the bovine estrous cycle: key concepts, studies, advancements, and terms. Journal of Dairy Science 83 1648-1658. (https://doi.org/10.3168/jds.S00220302(00)75033-8)

Jimenez-Krassel F, Ireland JLH, Kronemeyer C, Wilson-Alvarado A \& Ireland JJ 2018 Development of the "waveless" bovine model. Animal Reproduction Science 195 80-88. (https://doi.org/10.1016/j. anireprosci.2018.05.009)
Kulick LJ, Kot K, Wiltbank MC \& Ginther OJ 1999 Follicular and hormonal dynamics during the first follicular wave in heifers. Theriogenology 52 913-921. (https://doi.org/10.1016/S0093-691X(99)00182-X)

Kulick LJ, Bergfelt DR, Kot K \& Ginther OJ 2001 Follicle selection in cattle: follicle deviation and codominance within sequential waves. Biology of Reproduction 65 839-846. (https://doi.org/10.1095/biolreprod65.3.839)

Lima FS, Ayres H, Favoreto MG, Bisinotto RS, Greco LF, Ribeiro ES, Baruselli PS, Risco CA, Thatcher WW \& Santos JEP 2011 Effects of gonadotropin-releasing hormone at initiation of the 5-d timed artificial insemination $(\mathrm{Al})$ program and timing of induction of ovulation relative to $\mathrm{Al}$ on ovarian dynamics and fertility of dairy heifers. Journal of Dairy Science 94 4997-5004. (https://doi.org/10.3168/jds.2011-4240)

Luo WX, Gumen A, Haughian JM \& Wiltbank MC 2011 The role of luteinizing hormone in regulating gene expression during selection of a dominant follicle in cattle. Biology of Reproduction 84 369-378. (https:// doi.org/10.1095/biolreprod.110.085274)

Martinez MF, Adams GP, Bergfelt DR, Kastelic JP \& Mapletoft RJ 1999 Effect of LH or GnRH on the dominant follicle of the first follicular wave in beef heifers. Animal Reproduction Science 57 23-33. (https://doi. org/10.1016/s0378-4320(99)00057-3)

McNatty KP, Heath DA, Hudson N \& Clarke IJ 1990 Effect of long-term hypophysectomy on ovarian follicle populations and gonadotropininduced adenosine cyclic 3',5'-monophosphate output by follicles from Booroola ewes with or without the F-gene. Journal of Reproduction and Fertility 90 515-522. (https://doi.org/10.1530/jrf.0.0900515)

McNeilly AS 1988 The control of FSH secretion. Acta Endocrinologica 119 31-40.

Mihm M, Crowe MA, Knight PG \& Austin EJ 2002 Follicle wave growth in cattle. Reproduction in Domestic Animals 37 191-200. (https://doi. org/10.1046/j.1439-0531.2002.00371.x)

Mihm M, Baker PJ, Ireland JLH, Smith GW, Coussens PM, Evans ACO \& Ireland JJ 2006 Molecular evidence that growth of dominant follicles involves a reduction in follicle-stimulating hormone dependence and an increase in luteinizing hormone dependence in cattle. Biology of Reproduction 74 1051-1059. (https://doi.org/10.1095/ biolreprod.105.045799)

Mihm M \& Evans ACO 2008 Mechanisms for dominant follicle selection in monovulatory species: a comparison of morphological, endocrine and intraovarian events in cows, mares and women. Reproduction in Domestic Animals 43 (Supplement 2) 48-56. (https://doi.org/10.1111/ j.1439-0531.2008.01142.x)

Moyle WR, Campbell RK, Myers RV, Bernard MP, Han Y \& Wang X 1994 Co-evolution of ligand-receptor pairs. Nature 368 251-255. (https://doi. org/10.1038/368251a0)

Nascimento AB, Souza AH, Guenther JN, Costa FP, Sartori R \& Wiltbank MC 2013 Effects of treatment with human chorionic gonadotrophin or intravaginal progesterone-releasing device after $\mathrm{Al}$ on circulating progesterone concentrations in lactating dairy cows. Reproduction, Fertility, and Development 25 818-824. (https://doi. org/10.1071/RD12104)

Padmanabhan V, Brown MB, Dahl GE, Evans NP, Karsch FJ, Mauger DT, Neill JD \& Van Cleeff J 2003 Neuroendocrine control of folliclestimulating hormone (FSH) secretion: III. Is there a gonadotropinreleasing hormone-independent component of episodic FSH secretion in ovariectomized and luteal phase ewes? Endocrinology 144 1380-1392. (https://doi.org/10.1210/en.2002-220973)

Pierson RA \& Ginther OJ 1988 Ultrasonic imaging of the ovaries and uterus in cattle. Theriogenology 29 21-37. (https://doi.org/10.1016/0093691X(88)90029-5)

Prata AB, Drum JN, Melo LF, Araujo ER \& Sartori R 2018 Effect of different chorionic gonadotropins on final growth of the dominant follicle in Bos indicus cows. Theriogenology 111 52-55. (https://doi.org/10.1016/j. theriogenology.2018.01.011)

Scaramuzzi RJ, Baird DT, Campbell BK, Driancourt MA, Dupont J, Fortune JE, Gilchrist RB, Martin GB, McNatty KP, McNeilly AS et al. 2011 Regulation of folliculogenesis and the determination of ovulation rate in ruminants. Reproduction, Fertility, and Development 23 444-467. (https://doi.org/10.1071/RD09161)

Schallenberger E, Schondorfer AM \& Walters DL 1985 Gonadotrophins and ovarian steroids in cattle 1. Pulsatile changes of concentrations in 
the jugular vein throughout the oestrous cycle. Acta Endocrinologica 108 312-321. (https://doi.org/10.1530/acta.0.1080312)

Taylor PD, Hillier SG \& Fraser HM 2004 Effects of GnRH antagonist treatment on follicular development and angiogenesis in the primate ovary. Journal of Endocrinology 183 1-17. (https://doi.org/10.1677/ joe.1.05685)

Turzillo AM \& Fortune JE 1990 Suppression of the secondary FSH surge with bovine follicular fluid is associated with delayed ovarian follicular development in heifers. Journal of Reproduction and Fertility 89 643-653. (https://doi.org/10.1530/jrf.0.0890643)

Webb R, Nicholas B, Gong JG, Campbell BK, Gutierrez CG, Garverick HA \& Armstrong DG 2003 Mechanisms regulating follicular development and selection of the dominant follicle. Reproduction 61 71-90. (https:// doi.org/10.1530/biosciprocs.5.007)

Webb R, Buratini J, Hernandez-Medrano JH, Gutierrez CG \& Campbell BK 2016 Follicle development and selection: past, present and future.
Animal Reproduction 13 234-249. (https://doi.org/10.21451/19843143-AR883)

Xu Z, Garverick HA, Smith GW, Smith MF, Hamilton SA \& Youngquist RS 1995 Expression of follicle-stimulating hormone and luteinizing hormone receptor messenger ribonucleic acids in bovine follicles during the first follicular wave. Biology of Reproduction 53 951-957. (https:// doi.org/10.1095/biolreprod53.4.951)

Received 27 July 2019

First decision 5 September 2019

Revised manuscript received 7 February 2020

Accepted 13 February 2020 